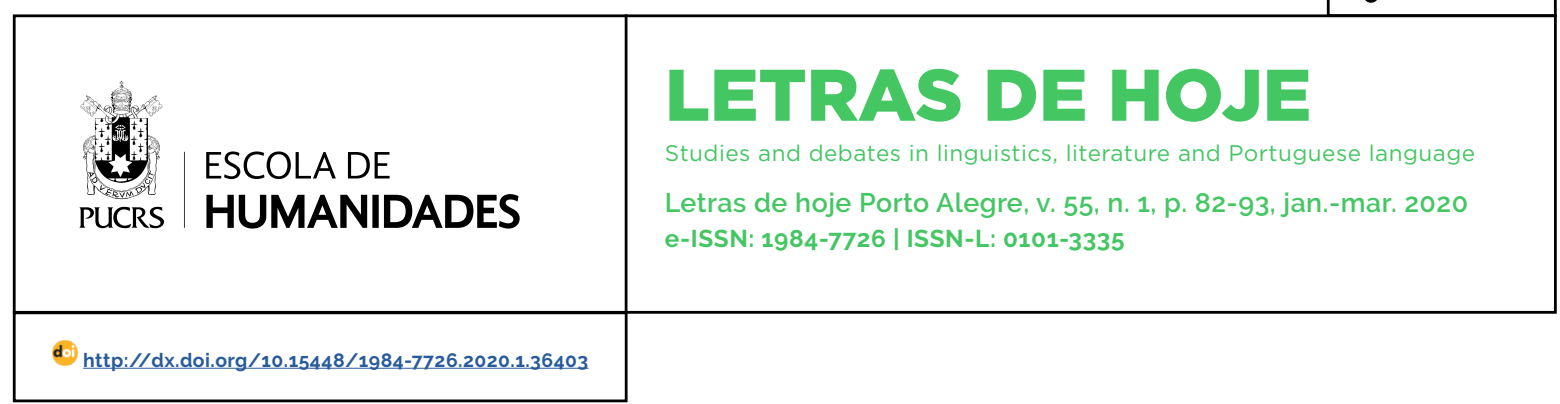

\title{
Adaptação em três atos: Shakespeare, Dobbs e BBC
}

\author{
Adaptation in three acts: Shakespeare, Dobbs and BBC \\ Adaptación en tres actos: Shakespeare, Dobbs y BBC
}

\section{Brunilda T. Reichmann ${ }^{1}$ orcid.org/0000-0002-4680-7462 brunilda.reichmann@gmail.com}

\section{Anuschka R. Lemos ${ }^{2}$ \\ orcid.org/0000-0003-0191-5731 anuschkalemos@gmail.com}

Recebido em: 12 nov. 2019 Aprovado em: 14 nov. 2019 Publicado em: 14 abr. 2020.
Resumo: Este texto dá continuidade ao artigo publicado sobre o diálogo que se estabelece entre a trilogia House of Cards, de Michael Dobbs, as séries da BBC e da Netflix e as peças de Shakespeare (Ricardo III, Macbeth e Otelo). O último volume da trilogia de Dobbs, The Final Cut [O último ato] e a T3 da BBC fazem referências a Júlio César, assunto até então não explorado por pesquisadores. Estamos, portanto, trabalhando apenas com o último romance de Dobbs e a última temporada da série da BBC - O ato final, enfatizando o protagonismo, a volubilidade do povo e a retórica em discursos proferidos por personagens de Shakespeare e de Dobbs, além da focalização espectatorial na série.

Palavras-chave: Júlio César. House of Cards. Série da BBC. Focalização espectatorial

Abstract: This paper continues the published research on the dialogue between Michael Dobbs' House of Cards trilogy, by Michael Dobbs, and the BBC and the Neflix series, and Shakespeare's plays - Richard III, Macbeth and Othello. The last volume of Dobbs' trilogy. The Final Cut, and its adaptation makes references to Shakespeare's Julius Caesar, a subject not previously explored. We turn our attention, therefore, to Dobbs' last novel and to the BBC series, emphasizing the protagonism, the volubility of the people, and the rhetoric in speeches delivered by Shakespeare's and Dobbs' characters, as well as to the viewer's focalization in the series.

Keywords: Julius Caesar. House of Cards. BBC series. Spectator's focalization.

Resumen: Este texto continúa el artículo publicado acerca del diálogo entre la trilogia House of Cards de Michael Dobbs, la serie BBC y Netflix, y las obras de Shakespeare (Richard III, Macbeth y Othelo). El último volumen de la trilogia de Dobbs, The Final Cut, y el T3 de la BBC hacen referencia a Julius Caesar, un tema no explorado previamente por los investigadores. Por lo tanto, estamos trabajando solo con la última novela de Dobbs y la última temporada de la serie de la BBC: The Final Act, haciendo hincapié en el protagonismo, la volubilidad de las personas y la retórica en los discursos de los personajes de Shakespeare y Dobbs, asi como el foco del espectador en la serie.

Palabras clave: Julio César. House of Cards. Serie de la BBC. Foco del espectador.

\section{(c) (1)}




\section{Introdução}

"Os textos shakespearianos são densos hipertextos que dialogam com múltiplas fontes por ele utilizadas e com a complexa rede de intertextos acumulada através dos séculos. De acordo com diversos criticos contemporâneos, as traduções e/ou adaptações/ apropriações das peças de Shakespeare compõem-se de um rico tecido semiótico-cultural que confere aos textos do bardo uma sobrevida que eles nunca teriam alcançado sem estas inúmeras variantes".3 (Camati e Miranda)

Nas considerações finais do artigo "Tá difícil competir": adaptação da trilogia de Michael Dobbs, pela BBC e pela Netflix"4 discutimos as relações de proximidade/distanciamento entre as peças Ricardo III, Macbeth e Otelo, de William Shakespeare, e o texto e as séries House of Cards. Enfatizamos, naquele trabalho, a motivação que leva lago, em Otelo, a se rebelar contra o seu superior, semelhante às motivações que levam os protagonistas da trilogia e das séries a se rebelarem contra seus superiores, assunto desencadeador das narrativas. A conspiração de lago faz dele um dos personagens mais estrategistas nas três peças, mas a sede de poder, a traição e a criminalidade caracterizam todas elas, especialmente Ricardo III e Macbeth. Ricardo "limpa" seu caminho ao trono do Reino Unido ao planejar o assassinato de irmãos e sobrinhos; Macbeth, ao escutar o terceiro vaticinio das bruxas - que será o rei da Escócia -, antecipa sua ascensão ao trono da Escócia ao matar, com estímulo e auxilio da esposa, o rei Duncan, seu amigo, enquanto ele se hospeda no palácio do casal.

A história da recepção de House of Cards (romances e séries) fora do Reino Unido e, em nosso caso, no Brasil, deu-se de modo que poderiamos classificar como "invertido". A maioria dos espectadores brasileiros entraram em contato primeiro com a série da Netflix, a última produção, na qual as temáticas - desejo insaciável pelo poder, criminalidade e corrupção na política - se desenvolvem em contexto norte-americano. Essa série foi ao ar pela primeira vez no início de 2013, formato streaming, e teve sua finalização em 2018, com o protagonismo passado a Claire Underwood [Robin Wright], devido ao afastamento involuntário do ator Kevin Spacey, protagonista masculino que desempenhava o papel de Francis Underwood. Os ecos de Shakespeare, principalmente de Ricardo III, Macbeth e Otelo, percebidos por aqueles que um dia leram ou assistiram as peças, levaram-nos, os receptores, a averiguar o hipotexto da série da Netflix, informação que é disponibilizada na abertura da maxissérie: "Baseada nos romances de Michael Dobbs \& na minissérie de Andrew Davies [BBC] (tradução nossa)"5. Ironicamente, no entanto, se perdemos as informações sobre os hipotextos, são os ecos de Shakespeare que despertam o espectador para possiveis apropriações de textos anteriores, deixando aparente as marcas palimpsésticas na série. Essas marcas, no entanto, tornam-se quase imperceptiveis no transcorrer da série norte-americana (73 episódios) pela imersão profunda e extensa no contexto político-cultural dos Estados Unidos e pelo afastamento gradativo e inevitável da maxissérie da trilogia de Michael Dobbs (House of Cards, To Play the King e The Final Cut) e da série The House of Cards Trilogy, da BBC (12 episódios).

Neste artigo, tentamos demostrar como a peça Júlio César, de Shakespeare, dialoga com o último volume da trilogia de Dobbs, House of Cards - o último ato, e com a Temporada 3 da série da BBC, o que não acontece com a série da Netflix. Nesse volume/temporada, a interculturalidade se dá entre o Reino Unido do final do século XX (texto de Dobbs e série da BBC) e Roma do ano 44 a.C. (Júlio César), ressaltando, aproximando e/ou ignorando caracteristicas e valores que permeiam a peça e a edição britânica de House of Cards. Apesar das marcas históricas deixadas pelo Império Romano, periodo pós-republicano da civilização romana, na época da peça Júlio César, Roma é

3 Excerto da Apresentação do livro Shakespeare sob múltiplos olhares, de Anna Stegh Camati e Célia Arns de Miranda.

4 REICHMANN, Brunilda Tempel. "Tá dificil competir": adaptação da trilogia de Michael Dobbs, pela BBC e pela Netflix, Ilha do Desterro: A Journal of English Language, Literatures in English and Cultural Studies, UFSC, v. 72, n. 1, p. 213-234, 2019. Ver também REICHMANN Brunilda T. House of Cards y Shakespeare: la influencia del dramaturgo en seriados contemporáneos. Trad. Célia Celli. Rev. Maria Ascensión Jiménez Martin. Scripta Uniandrade, v. 15, n. 3. p. 1-31, 2017.

5 Do original: Based on the novels by Michael Dobbs \& the mini-series by Andrew Davies. 
ainda uma república, um estado governado, há quase 500 anos, por senadores e magistrados, sem a presença de um monarca único e absoluto. A maior preocupação de Brutus, afirmada por ele e reafirmada por Marco Antônio na peça de Shakespeare, é a manutenção da república, que se via ameaçada pelas atitudes suspeitas, radicais e prepotentes de Júlio César, um comandante militar de destaque: a suposta relutância em rejeitar a coroa quando essa the é oferecida três vezes no início da peça, a incapacidade de perdoar um companheiro, a crença de que ele nunca errava e sua "aceitação" em ser coroado imperador no dia 15 de março de 44 a.C. - nos Idos de Março. Júlio César aparece no texto e na série da BBC House of Cards como representação e citação, como o texto de cabeceira e última leitura de Francis Urquhart, como reprodução retórica do discurso de Marco Antônio no discurso de Urquhart para destruir seu opositor e candidato a primeiro-ministro, Thomas Makepeace que, até aquele momento, tinha a vitória como primeiro-ministro garantida.

\section{A peça dentro do romance}

Em House of Cards - o último ato, Urquhart está no terceiro mandato como primeiro-ministro. A preocupação com a idade, com a falta de energia e com a aparência, com o previsivel final da carreira política e com a insatisfação do povo britânico com sua atuação deixam Urquhart suscetivel, fragilizado e inseguro. "Urquhart olhou para a própria imagem no espelho. O tempo havia cobrado um preço alto: seu rosto estava cheio de rugas; o cabelo, ralo; os olhos vitreos, sem vida, cansados" (DOBBS, 2016, p. 223). Mas ele finge ser o mesmo homem forte e poderoso do passado, a ser temido pelos colegas de partido e adversários. Sua esposa, Mortima, surge mais forte e companheira, orgulhosa e consciente do amor que o marido the dedica; assim como Elizabeth, nome utilizado na série, tem um papel primordial no desenvolvimento da terceira temporada. O casal está mais unido do que nunca e para comemorar o aniversário de casamento, vão a Royal Shakespeare Company, assistir à peça Júlio César, de Shakespeare.

\begin{abstract}
Chegaram tarde e fizeram uma entrada triunfal, quase régia. Depois de onze anos na Downing Street, sabem como aparecer em público. Mortima, sempre muito bem-vestida, deixou todos boquiabertos com seu vestido de noite de veludo negro com decote alto, adornado por um pendant de diamantes e esmeralda que capturavam e refletiam a luz do teatro, deixando todas a mulheres ao seu redor maravilhadas. [...] - Le roi est arrivé (DOBBS, 2016, p. 31).
\end{abstract}

Qual a surpresa do primeiro-ministro, no início da peça, quando percebe que o ator que interpreta Júlio César, com o rosto carregado pela maquiagem, tem a sua aparência. "A plateia começou a rir. César fizera sua primeira entrada em cena, com uma maquiagem pesada que o deixava muito parecido com Francis Urquhart" (DOBBS, 2016, p. 34). O primeiro-ministro percebe o momento delicado e, acostumado a reagir imediatamente em situações inesperadas, não é apenas o primeiro puxar o cordão de risadas, mas acena o seu lenço branco ao produtor do espetáculo, fazendo de conta que apreciava a comicidade e a criticidade da cena e "entrava na brincadeira".

Em Júlio César, os personagens que mais se destacam, desde o início da peça, são Brutus e Marco Antônio, mas os diálogos e as ações são todas centradas no reconhecimento popular da grandiosidade militar do general Júlio César.

No contexto especifico relevante para a peça, Júlio César integrava uma aliança política com Crasso e Pompeu, conhecida como Triunvirato. O sucesso de César nas Guerras Gálias estendeu o poder de Roma até a Britânia e o Reno, dando-lhe prestígio e poder político. Este fato, aliado à morte de Crasso, na Batalha de Carras, e de Júlia - filha de César e esposa de Pompeu -, desestabilizou o equilibrio de poder entre César e Pompeu. Pompeu alinha-se com o Senado, que determina a César que dissolva seu exército e retorne a Roma. César desafia as ordens e volta à Roma à frente de suas legiões, violando a lei que impedia generais de marcharem com exércitos para além do Rubicão. Ao atravessar o rio, César teria pronunciado a frase célebre: Allea jacta est ("A sorte está lançada"). Instaurada a guerra civil, César sagra-se vitorioso e assume o poder absoluto. A República assistia o início do seu fim (BARROSO, 2017, p. 392). 
No terceiro romance de Dobbs, a presença de Francis Urquhart é também menos extensa do que nos romances anteriores, similar à de Júlio César, na peça de Shakespeare. Além disso, Urquhart é um personagem híbrido, um amálgama de Júlio César, Marco Antônio e Brutus: ele deseja a grandiosidade de Júlio César, imita a retórica de Marco Antônio para manipular a reação popular - a volubilidade do povo da Inglaterra assemelhase a volubilidade do povo de Roma ao ouvir os discursos de Brutus e Marco Antônio - e comete "suicídio", assim como Brutus. Enquanto o suicídio de Brutus é uma "resolução" momentânea, o de Urquhart é planejado com maestria. Ao apontar essas apropriações, esclarecemos que algumas delas estão presentes apenas no romance de Dobbs, enquanto outras estão presentes tanto no romance como na série da BBC. Indicaremos essa distinção ao discorrermos sobre cada assunto.

As comparações e fricções entre os textos analisados trazem à lembrança o texto de Barthes, onde ele diz que

Sabemos agora que um texto não é feito de uma linha de palavras a produzir um sentido único, de certa maneira teológico (que seria a "mensagem" do Autor-Deus), mas um espaço de dimensões múltiplas, onde se casam e se contestam escrituras variadas, das quais nenhuma é original: o texto é um tecido de citações, saídas dos mil focos da cultura (BARTHES, 1988, p. 68)

Considerando esse tecido de citações em obras artísticas, Linda Hutcheon volta-se para a recepção de tais produções. Ela firma que "para que uma adaptação seja bem-sucedida em si mesma, ela deve satisfazer tanto o público conhecedor quanto o desconhecedor" (HUTCHEON, 2013, p. 166), sendo esse um dos grandes desafios do adaptador. É esperado que alguns espectadores não identifiquem ou não deem importância às apropriações dessa peça de Shakespeare no último romance de Dobbs e/ou na Temporada 3 da série da BBC, mas a recepção deverá ainda assim satisfazê-lo, mesmo sendo diferente da recepção do conhecedor. Aqueles que não conhecem a peça de Shakespeare não apreenderão a multiplicidade de camadas ou pluralidade de significados que a série oferece aos conhecedores, mas responderão, mesmo assim, à produção.

A razão da minha confiança é que acredito firmemente que a adaptação é (e sempre foi) central para a imaginação humana em todas as culturas. Nós não apenas contamos, como também recontamos nossas histórias. E recontar quase sempre significa adaptar - "ajustar" as histórias para que agradem seu novo público. Mesmo antes do advento do mundo globalizado atual, no qual a internet (e inclusive antes disso, com a televisão e o rádio) assegura que qualquer história será eventualmente recontada em algum lugar do mundo, todas as culturas estiveram envolvidas com traduções interlinguais e adaptações interculturais (HUTCHEON, 2013, p. 10).

Laurent Jullier e Michel Marie (2009, p. 70) sugerem que, no âmbito do texto audiovisual, o espectador conhecedor é uma das peças de uma dinâmica de "cumplicidade", onde se espera uma cultura comum como base entre produtores e espectadores. Caso a mesma base não exista, a dinâmica ou o jogo, como os autores afirmam, é de "participação", na qual "o espectador participa da cena graças a uma capacidade mental chamada de 'teoria do espírito'" (2009, p. 68) em que o espectador se une à narrativa audiovisual, em uma posição de convidado.

\section{O protagonismo entre Júlio César e Francis Urquhart e a convocação do espectador em House of Cards}

Uma produção intertextual implica em "uma relação de co-presença entre dois ou vários textos, isto é, essencialmente, e o mais frequentemente, como presença de um texto em outro" (GENETTE, 2005, p. 9). Não há como negar que Júlio César está presente em O último ato. A própria fisicalidade da obra de Shakespeare acentua essa proximidade e inter-relação. Júlio César é a peça que está nas mãos de Urquhart em vários momentos do romance e da série, sendo o último livro folheado pelo primeiroministro nas duas produções. No entanto, se atentarmos para o protagonismo de Júlio César, veremos que ele está presente poucas vezes até o início do Ato III da peça, quando é então 
assassinado pelos seus companheiros. Mas ele é o assunto das discussões e conversas na primeira metade da peça, e os acontecimentos na segunda metade são consequências de sua morte. Barbara Heliodora discorre sobre o questionamento do protagonismo de Júlio César na Introdução da tradução da peça: "Ele [Júlio César] merece ser o personagem-título da obra, no entanto, exatamente porque toda a primeira parte é dedicada ao planejamento de sua morte, enquanto tudo que acontece depois de seu assassinato, no início do Ato III, é dedicado à vingança dessa mesma morte" (2014, p. 7).

Independentemente da presença menos extensa, mas não menos importante, de Júlio César, desde o início da peça, as falas e atitudes de Brutus giram em torno da manutenção da república, do perigo de Júlio César tonar-se imperador e das implicações da presença/ausência de um imperador para o povo de Roma. Marco Antônio é o defensor de Júlio César, sem pensar nas consequências que a coroa traria ao povo de Roma.

[...] foi possivel para Shakespeare identificar Brutus como um político convicto... não havia homem no mundo... que valesse a perda de qualquer parcela dos direitos e deveres do cidadão... enquanto para Marco Antônio, militar e aristocrata, na verdade a maioria dos cidadãos preferia cuidar de sua vida do que pensar no Estado (HELIODORA, 2014, p. 8).

Urquhart também divide o seu protagonismo, no romance, com Thomas Makepeace, primeiro Ministro das Relações Exteriores de seu governo e depois seu antagonista, e com a própria narrativa que dedica páginas e páginas à discussão da situação político-econômica da ilha de Chipre e o envolvimento dos britânicos como mediadores no conflito entre turcos-cipriotas e gregos-cipriotas.

A distinção mais marcante entre Júlio César e Urquhart reside no fato que Júlio César rejeita, mesmo sendo uma rejeição questionável, a coroa simbólica que lhe é oferecida por Marco Antônio, três vezes. Eis a narrativa feita por Casca a Brutus e Cassius sobre a rejeição de Júlio César, sob aclamação do povo de Roma:
CASSIUS

Quem the [a Júlio César] ofereceu a coroa?

CASCA

Ora, Antônio.

BRUTUS

Conte-nos como tudo se passou, meu bom Casca.

CASCA

Podem me enforcar se eu souber contar como tudo se passou; fo tudo uma tolice, eu não reparei. Eu vi Marco Antônio oferecer-lhe uma coroa; mas não era bem uma coroa era mais uma coroinha de enfeite: e, como eu thes disse, segundo eu penso, ele bem que queria ficar com ela. Então ele a ofereceu uma segunda vez, e ele tornou a recusar: mas, segundo penso, estava com bastante vontade de botar a mão nela. E então a ofereceu pela terceira vez. Ele a afastou pela terceira vez; e no momento em que ia recusando, a ralé guinchava e aplaudia com suas mãozinhas gordas, e jogava os bonés para o alto, e soltava uma montanha de mau hálito, só porque César recusava a coroa, o que deixou César sufocado, pois ele desfaleceu e caiu (SHAKESPEARE, 2014, p. 27-28).

Não "foi tudo uma tolice" nem Casca deixou de reparar. No dia seguinte, apesar das premonições sobre os Idos de Março, do pesadelo de Calpúrnia, sua esposa, e dos augúrios, Júlio César é convencido por Décius a ir ao Senado, pois esse resolvera "Conceder hoje uma coroa a César;/ Mas se mandar dizer que não vai/ Talvez mudem de ideia" (SHAKESPEARE, 2014, p. 55). Esse argumento é suficiente para levar Júlio César ao Senado, onde é assassinado.

Urquhart, por outro lado, nunca rejeitou qualquer possibilidade de chegar ao cargo de primeiroministro; aliás, abriu o seu caminho até 10 Downing Street utilizando todas as artimanhas, manipulações e iniquidades possiveis. Ao não ser recompensado com o cargo que esperava do primeiro-ministro que ajudou a eleger, tem início sua trajetória política para chegar ao topo - depor o primeiro-ministro eleito e tomar seu lugar - sem considerar a quem poderia prejudicar ou mesmo destruir. Se Júlio César é comparado a uma serpente ainda por nascer - "um ovo de serpente / que chocado, segundo seu destino, / virá a ser maligno, e deve 
então / ser morto inda na casca" (SHAKESPEARE, 2014, p. 38) - Urquhart é a serpente que já quebrou sua casca, rasteja e ataca, desde o momento em que inicia a sua vingança, nem que para isso tenha que destruir todos que se colocam em seu caminho. "O poder político pertence à categoria do poder do homem sobre outro homem [...] Esta relação de poder é expressa de mil maneiras..." (BOBBIO et alii, 2010, p. 955), e em House of Cards, seja no romance ou nas séries, é expressa da maneira mais infame e sórdida possivel.

No último volume, Urquhart está no cargo há 11 anos, poucos dias a menos do que a exprimeira-ministra Margaret Thatcher, mencionada no romance e na série. O protagonismo de Urquhart, como mencionado anteriormente, é dividido com Thomas Makepeace, também do partido conservador e Secretário das Relações Exteriores, quando esse escolhe, por ter suas funções boicotadas, fazer oposição ao primeiroministro. Makepeace, nome simbólico para um possivel sucessor de Urquhart, luta para tornar públicos (após conhecer Maria Passolides, filha de Evanghelos Passolides e sobrinha dos dois adolescentes mortos, no passado, por Urquhart na itha de Chipre) os arquivos dos cipriotas assassinados em Chipre, há quatro décadas, para descobrir os agentes britânicos responsáveis pelos atos e o local onde os corpos foram enterrados. No romance, Maria e Makepeace tornam-se amantes desde o primeiro encontro. Na série, eles permanecem amigos, lutando pela mesma causa. Ela faz da motivação de seu pai - descobrir os corpos de seus dois irmãos cipriotas, George e Euripedes, assassinados - a causa de Makepeace, e no final da longa jornada política, Makepeace chega a Londres com mais de 40 mil seguidores, em vésperas à eleição do próximo primeiroministro. Ele é aclamado pelo povo que, cansado da política de Urquhart, o apoia com entusiasmo. Esse entusiasmo perdura até a chegada e o discurso de Urquhart no comício de Makepeace.

Mais de quarenta mil pessoas haviam se reunido... até que a Trafalgar Square transbordou e extravasou com entusiasmo geral. Makepeace caminhou por entre a massa como se fosse Moisés abrindo o Mar Vermelho, suas mãos levantadas acima da cabeça, os punhos fechados para imitar algemas. A multidão rugiu em aclamação (DOBBS, 2016, p. 410).

Portanto, além de dividir a cena com Makepeace, questões políticas que envolvem Chipre, o Reino Unido e a França tomam grande parte do último volume da trilogia. A deswoberta de um gigantesco lençol de petróleo na costa de Chipre - assunto ainda sigiloso - vai implicar na divisão da ilha entre turcos e gregos cipriotas e tornar-se informação privilegiada para um juiz incorruptível. Essas questões tiram o foco de Urquhart para movê-lo em direção à ilha e à Inglaterra.

Na série, essas questões são vistas pela ótica do primeiro-ministro e sua esposa; portanto, Urquhart permanece como protagonista, dividindo a cena com Makepeace, sim, e Elizabeth, que sai do plano de fundo e contracena com ele. Ela é força quando ele esmorece, conforto quando ele se desespera, detentora do destino dele, quando ele acha que está velho e derrotado, política e humanamente falando. Elizabeth dispõe-se a "seduzir" politicamente o presidente turco, a passar ingenuamente informação privilegiada ao juiz britânico incorruptivel e a confrontar desafiadoramente o comportamento do mesmo juiz que presidira a divisão das terras de Chipre, mostrando que o tinha nas mãos. Ela transita pelas cenas com o mesmo malabarismo político que seu marido e, no final, determina quando ele deve sair de cena.

Outra personagem que continua em cena, interlocutora e testemunha dos pesadelos, desejos e jogos políticos de Urquhart, é o espectador. "Todos os filmes [audiovisuais] modelam um 'espectador ideal', que coopera no máximo com suas possibilidades" (JULLIER; MARIE, 2009, p. 68). Desde a primeira temporada, em diversos momentos, seja em uma cena em que apareça sozinho, seja em uma caminhada pelo Parlamento com seus assessores, Urquhart dirige-se ao espectador da trama, confidencia pensamentos, estabelecendo um outro jogo de cumplicidade, diferente do citado anteriormente. Seu olhar para a câmera, seu tom de voz secreto e ainda assim livre, revela o local do espectador, quebrando o artifício de uma suposta invisibilidade e distanciamento. 


\begin{abstract}
Sabe-se que o olhar dirigido diretamente para a câmera é comum na fotografia eé regra na televisão, enquanto no cinema, mesmo no cinema documental, tem um efeito francamente transgressivo. Igualmente, o plano frontal é bastante frequente na fotografia (notadamente nos retratos de pessoas ou de paisagens), quase uma lei na televisão, mas tão raro no cinema que, quando usado sistematicamente [...], produz um efeito "teatral" ou, como se costuma dizer, "anticinematográfico" (MACHADO, 2007, p. 71).
\end{abstract}

Próximo aos recursos retóricos do teatro ou da televisão noticiosa, aqui a constante convocação do espectador para o espaço da diegese como confidente do primeiro ministro, em um plano frontal, além da revelação de memórias em flashbacks, revelam-se como recursos de proximidade ao humanizar o personagem principal da trama. O fato de usar esse recurso de "olhar para o espectador" nas mais diferentes cenas, muitas vezes em planos-sequências, onde o primeiro ministro conversa com outros personagens, direciona-se ao espectador e retorna à cena, confere um certo protagonismo ao espectador, ao ser aquele com o qual Urquhart divide confidências. Essa questão será desdobrada adiante neste texto.

\section{A retórica de Marco Antônio e Urquhart e a volubilidade do povo}

Ambos, Marco Antônio e Urquhart, usam uma retórica elogiosa para elevar os ânimos de seus ouvintes e destruir seus alvos: Brutus, que tentara justificar o assassinato de Júlio César, e Makepeace, que tem o apoio popular maciço dos britânicos para chegar ao cargo de primeiroministro. Assim fala Brutus aos "plebeus" para justificar seu ato criminoso.

\section{BRUTUS}

Ouvi com paciência até o fim. Romanos, compatriotas e amigos! [...] Se então ele [alguém] perguntar por que Brutus levantou-se contra César, esta é a minha resposta: não foi porque amei menos a César, mas porque amei mais a Roma. Preferirieis vós que César estivesse vivo, para que morrêsseis todos escravos, a que César estivesse morto, para viverdes livres? (SHAKESPEARE, 2014, p. 74).
Brutus continua com o seu discurso racional e, no final, dá permissão e faz uma introdução calorosa a Marco Antônio, antes de afastar-se, imaginando que o companheiro endossará seus ideais republicanos e a sua participação no assassinato. Marco Antônio inicia o seu discurso diante do corpo ensanguentado de César e faz uma campanha sutil e velada para que os ouvintes se voltem contra Brutus. Ele deixa claro que o seu propósito não é engrandecer César, expressando que está, aparentemente, ao lado dos que o eliminaram. No entanto, durante o seu discurso, Marco Antônio vai minando a crença do povo sobre a apreciação de Brutus - que César era ambicioso - ao falar sobre o bem que ele fez a Roma. Paralelamente à repetição do qualificativo de que Brutus era um homem honrado, ele vai mostrando "evidências" da generosidade de César a Roma e aos romanos. Eis algumas das frases de Marco Antônio:

\section{ANTÔNIO}

Amigos, cidadãos de Roma ouvi-me: Venho enterrar a César, não louvá-lo. [...] o honrado Brutus

Disse que César era um homem ambicioso:

[...]

Com permissão de Brutus e dos outros

(Pois Brutus é um homem muito honrado,

Tal como os outros, todos muito honrados.)

[...]

Ele [César] trouxe pra Roma mil cativos Cujo resgate enchia os nossos cofres; Mostrou-se assim a ambição de César? [...]

Vós todos vistes que, no Lupercal, Três vezes the ofertei a real coroa: Três vezes recusou. Isso é ambição? Mas Brutus diz que ele era ambicioso E sabemos que é um homem muito honrado.

[...]

Eis um escrito com o selo de César; [...]

E, homens, conhecendo o testamento vós ficarieis loucos inflamados (SHAKESPEARE, 2014, p. 77-80, grifo nosso).

Paulatinamente, incitados pelo discurso de Marco Antônio, os ouvintes começam a se revoltar contra os assassinos de César, principalmente 
Brutus. Marco Antônio intensifica a sua "campanha" ao se voltar para o corpo de César e mostrar as marcas dos ferimentos causados pelos assassinos - Cassius, Casca e Brutus. Intensifica também a dramaticidade ao falar do amor que César dedicava a Brutus, "o anjo de César" e arremata a cena mostrando ao povo "como a traição feriu o corpo" do grandioso militar. Então, cautelosa e sabiamente, Marco Antônio volta-se novamente ao testamento, para demonstrar como o povo romano seria beneficiado por César.

ANTÔNIO

Bons amigos, não quero eu instigar-vos Uma repentina onda de revolta. Os que fizeram isso [mataram César] são honrados,

[...]

Aqui está ele [o testamento], e selado por César.

Aos cidadãos romanos ele deixa, A cada um, setenta e cinco dracmas. [...]

Além disso deixou-vos seus passeios Seus bosques e pomares mais recentes (SHAKESPEARE, 2014, p. 83-84).

$\mathrm{Na}$ verdade, Marco Antônio incita, com a sua retórica repetitiva, frases paralelas e aparentemente elogiosas, os romanos a se revoltarem contra a injustiça cometida contra César. Eles pegam o cadáver de César e o levam, com a missão de perseguir os assassinos. Os mesmos ouvintes que aplaudiram Brutus momentos antes e que concordaram com a sua atitude drástica para manter a república, agora clamam por justiça, por vingança. Cassius e Brutus são forçados a fugir de Roma.

Voltando nosso olhar para House of Cards, temos agora que apresentar o romance e a série separadamente, pois elas têm finais bem distintos. No romance, Urquhart diz querer "dar uma passada na festinha de Tom Makepeace" (DOBBS, 2016. p. 411). Essa "festinha" é a aglomeração de mais de 40 mil pessoas que o seguem e aguardam na Trafalgar Square o discurso final da campanha para primeiro-ministro de Thomas Makepeace. Urquhart escuta o clamor da multidão e pensa: "Era melhor só acreditar em si mesmo, morrer como um César em vez de um humilde pecador" (DOBBS, 2016, p. 410). Essa decisão não é motivada apenas pelo ruído da multidão que aclama Makepeace, pois, em retrocesso, vemos todos os passos tomados pelo primeiro-ministro para entrar para a História como um herói e impedir a ascensão política de Makepeace. Um dia antes da chegada de Makepeace a Londres, Urquhart manda incendiar o pequeno restaurante, em Londres, de Evanghelos Passolides, o grego cipriota, pai de Maria e irmão dos adolescentes que ele matara quando era tenente em Chipre, aos 23 anos. Passolides desconfia que Urquhart tenha sido o responsável, mas não tem provas. Ao voltar de suas compras, o cipriota vê seu pequeno restaurante em chamas. Um enviado de Urquhart lhe entrega então um envelope onde o nome do tenente responsável pela morte de seus irmãos não está rasurado, é o próprio Urquhart. No dia seguinte, o primeiroministro tem que se expor para que a bala do revólver de Passolides o alcance, e para que possa destruir os anseios políticos de Makepeace, ao tornar-se um herói. Nada melhor do que aparecer em público no palanque do opositor. Corder, seu segurança, que desconhece todo o plano, discorda de sua ida ao comício e diz:

- O senhor passou por um estresse
muito grande nos últimos dias. Será que
isso... - fez uma pausa, constrangido -...
está afetando seu julgamento?
- Muito diplomático de sua parte.
Obrigado. - Urquhart aproximou-se
para colocar as mãos sobre o ombro do
agente. - Mas é justamente o oposto,
meu velho amigo. O estresse de que
você está falando deu-me uma no-
tável lucidez. Parafraseando Samuel
Johnson, "quando um homem está
prestes a ser enforcado, sua mente
adquire um foco notável". Sei o que
estou fazendo. Absolvo-o de qualquer
responsabilidade (DOBBS, 2016, p. 411).

Mas, como em poucos momentos do terceiro volume da trilogia, Urquhart sente-se eufórico ao arquitetar um plano e executá-lo com perfeição. Geralmente, seus planos incluem a destruição de um colega político, mas, desta vez, é a ambição de entrar para a História que o move e o enche de energia. Na manhã do dia do assassinato, Urquhart toma um banho bem demorado, escolhe o seu melhor terno e prepara-se para o que considera 
o "seu triunfo final". O último livro que folheia é Júlio César, a peça de Shakespeare. No momento em que se dirige para o palanque, acompanhado de Mortima e Corder, Urquhart é vaiado pela multidão, mas Makepeace cede-lhe a palavra, dizendo: "Vamos ouvi-lo antes de condená-lo" (DOBBS, 2016, p. 417). Urquhart levanta as mãos para o céu e diz: "Povo da paz! Eu o saúdo" (DOBBS, 2016, p. 417) e argumenta que a sua ambição de chegar e permanecer na Downing Street era e é uma ambição de fazer o melhor pelo seu país, utilizando a retórica de Marco Antônio.

Ambicionei meu cargo porque não existe um privilégio maior ou uma glória mais elevada na vida de um político, do que liderar este país e vocês, seu povo. Foram muito gentis em me conceder essa honra por mais de dez anos seguidos. E se agora decidiram negá-la a mim outra vez, não posso reclamar. Certamente, não contra Tom Makepeace., pois ele é um homem honrado. [...]

Ouviram-se protestos na multidão.

- Não! Nem mesmo de Tom Makepeace, porque ele foi membro de meu governo durante muitos anos. E ele é um homem honrado. [...] Há pouco, Tom disse que devo desculpas a vocês e eu escutei as suas palavras, as palavras de um homem honrado, com todo cuidado (DOBBS, 2016, p. 417-418, grifo nosso).

Assim continua Urquhart até ver Passolides serpentear o seu caminho entre a multidão. Seu timing é perfeito e ele rouba "o momento para si". Makepeace é esquecido. O primeiro-ministro continua olhando fixamente para Passolides que chega à primeira fila da multidão. "Talvez eu tenha amado demais a minha pátria. Nesse caso, foi um erro, um engano fatal. E serei obrigado a pagar por ele" (DOBBS, 2016, p. 419), ecoando o discurso de Brutus ao falar de seu amor pela pátria.

A boca de Passolides tremia em revolta Seus olhos tintos de sangue. [...]

- Não tenho familia além de Mortima. [...] Ninguém mais aplaudia o nome de Makepeace ou queria demonstrar ligação com ele. Urquhart os tinha nas mãos, os conquistara. A peça estava chegando ao fim. [...]

- Talvez ele [Makepeace] tenha o direito de chamá-los assim [de irmãos e irmãs]. Mas se ele reivindica os vivos, deixe que eu reivindique os mortos.
Passolides parecia estar em lágrimas, a boca aberta. Urquhart queria os mortos, George, Euripedes [seus irmãos]. Aquele homem era o diabo encarnado (DOBBS, 2016, p. 420).

Urquhart então ousa falar em Chipre e nos muitos ingleses que nutriam nobres ideais e pagaram com suas vidas a paz que ele tanto perseguira, sua provocação final ao cipriota que o observa fixamente. Passolides, tomado pelo ódio que perdura mais de quatro décadas, dispara sua arma. Urquhart fica sem ar. Uma mancha aparece em sua camisa branca, uma segunda mancha. Sente seus joelhos cederem. Olha para Mortima e tenta abraçá-la, protegê-la. "[Urquhart] Não sentia nada. Apenas um pouco de exaustão. E um pouco de euforia. Por tê-los enganado, até o final. Mesmo à custa de seu próprio final" (DOBBS, 2016, p. 421). Mortima o beija, ele sorri e murmura: "- Grandes ruinas..." Assim como Brutus lança-se sobre a espada para provocar sua morte, Urquhart é quem decide e planeja o seu final. Passolides é alvejado por Corder e morre antes de Urquhart, relata Dobbs no Epílogo. Urquhart é velado em Westminster e a multidão que lhe presta homenagem não tem fim. Nenhuma palavra é dita sobre Thomas Makepeace, o candidato praticamente eleito pela mesma multidão que, no final, homenageia Urquhart. O discurso e a morte de Urquhart garantem o seu lugar na História e a permanência do partido conservador no poder. A volubilidade do povo inglês assemelha-se a volubilidade do povo romano ao escutar os discursos de Brutus e Marco Antônio. Como vemos, nesse último volume, o protagonista se apropria de características de César e Marco Antônio na vida e de Brutus na morte.

Na Temporada 3 da série da BBC, os adaptadores retiram de Urquhart a característica de grande estrategista e a diegese afasta-se da peça Júlio César no final. O assassinato do primeiro-ministro é planejado pela esposa, Elizabeth, e pelo agente, Corder, pois eles percebem que não há mais como salvar Urquhart da derrota e do fracasso no final de sua carreira como Chefe do Governo da Grã-Bretanha, a não ser fazendo dele uma vítima do povo que deveria admirá-lo e honrá-lo. 
Corder contrata um snipper para matar o primeiroministro no momento da inauguração da estátua de Margaret Thatcher, no pátio do Parlamento. Perde-se assim o meticuloso planejamento e o perfeito timing da mente maquiavélica de Urquhart, além de transformar Makepeace em cúmplice no assassinato, pois Corder, após o ato, confabula com ele e promete-lhe lealdade. Com o assassinato consumado, cujo responsabilidade recai sobre Passolides, Urquhart recupera a dignidade perdida e entra para a História como o primeiro-ministro que mais tempo permaneceu no cargo, ultrapassando em alguns dias o tempo de Margaret Thatcher.

Desde a proposta de instalação da estátua de Thatcher, Urquhart usa de todos os recursos para evitar que tal "desfaçatez" aconteça. Ele odeia a ideia de que ela possa continuar a ser a primeira-ministra que mais tempo permaneceu no poder e que uma estátua seja erguida em sua homenagem. No entanto, acompanhamos, juntamente com Urquhart e Elizabeth, todos os passos da instalação, desde a preparação do terreno, apesar de todas as medidas tomadas por Urquhart para impedir que a estátua seja realmente instalada e inaugurada. Ele é incapaz de impedir que tal homenagem aconteça. A inauguração da estátua acaba sendo, ironicamente, o cenário de sua morte. A preparação da instalação e a inauguração da estátua estabelece um paralelismo irônico com a preparação e morte do primeiro-ministro. A estátua se ergue, Urquhart, tomba.

A força política de Urquhart está debilitada pelo passar do tempo, assim como a sua saúde mental e estado emocional - outro propósito da série, ao alterar o grau de crueldade do primeiroministro e a intensificar os seus problemas emocionais, tornando os acontecimentos mais palatáveis e o protagonista mais humano ao espectador da série. Nela o protagonista é continuamente perseguido pelas lembranças de crimes do passado, principalmente dos crimes cometidos contra os adolescentes em Chipre e contra a jornalista e amante Storin. Enquanto no romance, o jovem tenente Francis Urquhart queima os dois adolescentes vivos, consciente do que está fazendo, na série ele atira contra os adolescentes e queima seus corpos depois de mortos para não serem identificados. A imagem da queima dos corpos se presentifica - "sentida como presente e integrada como tal na memória" - em vários momentos da série, até porque a abertura dos arquivos do passado pode expor o seu envolvimento. Urquhart é realmente tomado pela imagem, é a presença da memória involuntária que o faz titubear em suas ações e passar mal repetidas vezes. A segunda imagem que lhe assola a mente é a imagem da queda de Storin, quando ele a joga sobre o parapeito da laje do último andar do Parlamento. Em uma infeliz decisão da equipe de adaptação, Storin tinha escolhido chamá-lo de "Daddy", dando uma conotação incestuosa e freudiana ao relacionamento. Enquanto o seu corpo cai até se chocar conta o capô de um carro, ela grita "Daddy" várias vezes. Seus gritos, perpetuados na memória de Urquhart, tomam-no também inesperadamente e ele se torna incapaz de agir nesses momentos. Como disse, ele não apenas se lembra dos momentos, ele os revive e essas vivências vão aniquilando o seu estado emocional e enfraquecendo as suas ações. As imagens do sofrimento, mesmo que involuntário de Urquhart, são intensificadas na série, tornando-o mais sensivel do que no romance.

Todas as cenas descritas são de conhecimento apenas do espectador. O Urquhart debilitado, a intensificação de suas memórias e a decrescente ironia em suas interlocuções com o espectador, são de conhecimento somente dele que é seu cúmplice. Nenhum dos personagens na trama sabe o tanto quanto aquele com quem o primeiro ministro divide confidências, ironias e imagens. Nenhum dos personagens vê as imagens mentais recorrentes em Urquhart, imagens dos assassinatos dos adolescentes em Chipre ou de Mattie. André Gaudreault e François Jost chamam esse recurso de "focalização espectatorial". Na narrativa audiovisual essa focalização se caracteriza quando 
[...] o narrador pode [...] oferecer uma vantagem cognitiva sobre os personagens ao espectador. Esse procedimento já era muito utilizado no teatro, graças à direção ou ao cenário, que davam ao espectador a possibilidade de acompanhar duas cenas simultaneamente, ou graças à convenção do aparte, que comentava os sentimentos do personagem sem o conhecimento dos outros (GAUDREAULT; JOST, 2009, p. 180).

Na série, a focalização espectatorial é especialmente forte pela relação que o protagonista estabelece com o espectador, mas é fundamental pensar que somente o espectador acompanha todos os outros personagens e as suas trajetórias na obra. Ele sabe das dinâmicas políticas, dos desejos, das tramas que cada um tece. Ele acompanha, com o distanciamento do invisivel, daquele que observa cada um, compreendendo como eles também jogam o tempo todo conforme seus interesses pessoais. A ascensão de Thomas Makepeace, as ações suspeitas de Claire Carlsen (secretária particular do primeiro ministro no terceiro volume), o pragmatismo de Elizabeth Urquhart são fatos que enfraquecem o personagem principal. A focalização espectatorial, então, confere ao espectador esse saber a mais, que ninguém na própria trama possui. Porém, como esse saber é colocado de duas formas diferentes, pessoal e próximo com o primeiro ministro, impessoal e distante com os outros, os laços abertos por Urquhart ganham uma força intima, promovendo uma relação de confiabilidade com o espectador, humanizando o protagonista.

No primeiro episódio da terceira temporada, Urquhart perde a linha de pensamento durante uma declaração ao plenário, permanece quieto por alguns instantes e disfarça a sua fragilidade com uma afirmação emotiva depois de alguns instantes. Essa fala é interpretada por diversos parlamentares como expressão do poder que ele ainda detém. Eles o admiram e aplaudem, enquanto o espectador sabe de onde vem seu conflito e vertigem - de imagens avassaladoras do passado. A própria situação pode ser relacionada à ideia de espectador descrita por Nick Browne, onde o espectador [...] é um pouco como o sujeito do sonho, um sujeito plural que vai se transfigurando ao longo do processo onírico. Ele está em vários lugares ao mesmo tempo, ele é e não é ele próprio, ele faz as vezes do observador e do observado simultaneamente. podendo ainda avaliar os clamores de cada um e responder a eles (BROWNE apud MACHADO, 2007, p. 94).

Importante destacar que autores como Machado, Gaudreault e Jost aproximam a experiência desse espectador à experiência do espectador de teatro, pois ele navega pelas cenas com informações e modulações emocionais que personagens desconhecem. Dessa forma, certas escolhas estruturais deixam a série ainda mais próxima à obra de Shakespeare.

\section{Considerações finais}

No primeiro artigo publicado sobre House of Cards (romances e séries), demonstramos como o protagonista Francis Urquhart dialoga com os personagens Macbeth, Ricardo III e lago. O perfil criminoso do protagonista em muito se assemelha a esses personagens shakespearianos, pois, como eles, Urquhart cometerá crimes monstruosos para se vingar, chegar ao poder e se manter nele. A quebra da quarta parede no romance e na série, tornando-nos ouvintes com informações criminosas privilegiadas, de certa forma, nos aproxima do protagonista, enquanto os outros personagens, sem tais informações, permanecem na ignorância da personalidade de Urquhart e de suas maquinações para atingir politicos com possibilidade de concorrer ao cargo de primeiro-ministro.

Já no terceiro volume da trilogia, House of Cards - o ato final, o diálogo mais intenso é com a peça Júlio César, de Shakespeare. Urquhart torna-se um amálgama de caracteristicas de Júlio César. Marco Antônio e Brutus. A ambição, mesmo que velada de Júlio César, é presentificada no primeiroministro. A retórica de Marco Antônio, com poder de transformar completamente a reação dos plebeus de Roma, é imitada por Urquhart que, ao "elogiar" continuamente Makepeace, destrói o apoio popular que ele conquistara com sua honestidade, seu carisma e comprometimento. 
Como Brutus, mas de forma muito mais elaborada no romance, Urquhart causa a sua própria morte. Brutus pede a um companheiro de batalha que segure a espada e se joga sobre ela para dar um fim à sua vida. Urquhart, planeja estrategicamente seu fim, cuidando de cada detalhe para que o seu assassinado seja consumado no comício de Makepeace, não antes de destruí-lo verbalmente. Isto no romance, porque na série, Urquhart não é esse estrategista, mas tem uma esposa que planeja resgatar sua dignidade por meio de seu assassinato na inauguração da estátua de Margaret Thatcher. Essa mudança no final retira o destino do protagonista de suas próprias mãos, enfraquecendo ainda mais um político em plena decadência. Além disso, implica na ideia de que Makepeace trilhará um caminho semelhante ao de Urquhart, ao tornar-se cúmplice no assassinato e possivel primeiro-ministro que o sucederá. Um homem de valor, um político íntegro e dedicado, Makepeace parece, no final, escolher o caminho da criminalidade e da corrupção, assim como o seu antecessor.

\section{Referências}

BARROSO, Luís Roberto. A tragédia de Júlio César: poder, ideal e traição. Anamorphosis - Revista Internacional de Direito e Literatura, Porto Alegre, v. 3, n. 2. p. 387-409, jul./dez. 2017. https://doi.org/10.21119/ anamps.32.387-409

BARTHES, Roland. O rumor da lingua. Trad. Mário Laranjeira. Disponivel em: http://www2.eca.usp.br/ Ciencias.Linguagem/L3BarthesAutor.pdf. Acesso em: 11 ago. 2019

BOBBIO, Norberto et al. Dicionário de política. Brasília: Editora Universitária de Brasília, 2010.

CAMATI, Anna Stegh; MIRANDA, Célia Arns de. Apresentação. In: CAMATI, Anna Stegh; MIRANDA, Célia Arns de. (org.). Shakespeare sob múltiplos olhares. Curitiba: Ed. Solar do Rosário, 2009. https://doi. org/10.17771/pucrio.tradrev.35364

DOBBS, M. House of Cards. Trad. Luis Reyes Gil. São Paulo: Benvirá, 2014.

DOBBS, M. House of Cards: xeque-mate. Trad. Carlos Haag. São Paulo: Benvirá, 2016.

DOBBS, M. House of Cards: o último ato. Trad. Carlos Haag. São Paulo: Benvirá, 2016.

GAUDREAULT, André e JOST, François. A narrativa fotográfica. Brasilia: Editora Universidade de Brasilia, 2009.
GENETTE, Gérard. Palimpsestos: a literatura de segunda mão. Edição bilíngue. Trad. Luciene Guimarães e Maria Antonia Ramos Coutinho. Belo Horizonte: UFMG, 2005.

HADFIELD, Andrew David (ed.). Julius Caesar: William Shakespeare. New York: Barnes \& Noble, 2007.

HELIODORA, Barbara. Introdução. In: Júlio César: William Shakespeare. Rio de Janeiro: Nova Fronteira, 2014. (Saraiva de Bolso)

HUTCHEON, Linda. Uma teoria da adaptação. Trad. André Cechinel. 2. ed. Florianópolis: Editora UFSC, 2013.

JULLIER, Laurent; MARIE, Michel. Lendo as imagens do cinema. São Paulo: Editora Senac São Paulo, 2009

LEMOS, Anuschka R. Da fotografia - seus espaços: articulações dinâmicas e experiências. Curitiba: Papirus, 2017.

MACHADO, Arlindo. O sujeito na tela. São Paulo: Papirus, 2007

REICHMANN, Brunilda T. House of Cards y Shakespeare: la influencia del dramaturgo en seriados contemporáneos. Trad. Célia Celli. Rev. Maria Ascensión Jiménez Martin. Scripta Uniandrade, Curitiba, v. 15, n. 3, p. 01-31, 2017. https://doi.org/10.5935/1679-5520.20170024

REICHMANN, Brunilda T. "Tá difícil competir": adaptação da trilogia de Michael Dobbs, pela BBC e pela Netflix, Itha do Desterro. A Journal of English Language, Literatures in English and Cultural Studies, Florianópolis, v. 72, n. 1, p. 213-234, 2019. https://doi. org/10.5007/2175-8026.2019v72n1p213

SHAKESPEARE, William. Júlio César. Trad. Barbara Heliodora. Rio de Janeiro: Nova Fronteira, 2014. (Saraiva de Bolso).

Endereço para correspondência:

Brunilda T. Reichmann ${ }^{1}$

Rua Desembargador Otávio do Amaral, 741

Bigorrilho

80730-400 Curitiba, PR

(41) 999779999

Anuschka R. Lemos²

UNIANDRADE - Rua João Scuissiato, 01

Santa Quitéria

80310-310 Curitiba, PR 